\title{
Urban Ecology as Model and Method: Collaboration and Multidisciplinary Work
}

\author{
STEPHANIE CARLISLE \\ University of Pennsylvania
}

\author{
NICHOLAS PEVZNER \\ University of Pennsylvania
}

Despite two decades of landscape urbanism theory suggesting the possibility of a shared project and a new hybrid discipline, the fields of landscape and architecture retain distinct pedagogies and practices. Many architects and landscape architects aspire to design within an expanded field of practice, but there is still quite a lot that architects and landscape architects misunderstand about each other's methods, techniques, and intellectual projects. Among these divisions, an over-reliance on objects has resulted in an underemphasis on systems, interactions, and context. Outdated conceptions of "nature" have limited both disciplines' agency to operate on socio-ecological designed landscapes. A shift in emphasis from objects to systems, and from pattern to function, may enable these disciplines to pursue a more functional design collaboration. Complex challenges facing tomorrow's cities will require the expertise of both architecture and landscape. Rather than merging into a hybrid discipline, architecture and landscape each have unique skills, modes and methods to offer. The real challenge is finding synthetic and radical forms of collaboration. The emerging field of urban ecology offers insights into how disparate disciplines may productively collaborate on a shared project of exploration and intervention without losing their disciplinary core, culture, methods, or perspective. With the urban environment increasingly recognized as a complex ecosystem of socio-ecological-technological relationships, urban ecology also offers new vocabulary and methodology for collaborative and interdisciplinary work on urban sites, with goals like ecological function, high performance, and ongoing long-term design engagement.

\section{INTRODUCTION}

Today's urban environment is increasingly recognized as a complex ecosystem of socio-ecological-technological relationships - one in which the natural, built, and cultural environments cannot be understood, much less designed, in isolation. ${ }^{1}$ This reconception of the contemporary city has created an opportunity for inclusiveness and collaboration between the disciplines of architecture and landscape. But despite two decades of landscape urbanism theory suggesting the emergence of a new hybrid discipline, landscape and architecture retain distinct pedagogies and practices. What is the relationship between these two disciplines, and have the two fused into a unified project, reflecting our contemporary desire for holistic thinking and systemic approaches to complex problems? If the building of the city is to be approached as a unified project, should there not be a unified practice?
Rather than bringing these two disciples closer together, the increased overlap in the conceptual and physical territory of practice has brought into focus the elements of these disciplines that stand in the way of radical collaboration and of the adoption of a shared project. Miscommunication between architecture and landscape results as much from outdated concepts of nature and the centrality of architectural objects, as it does from unworkable ideas of disciplinary autonomy and lack of familiarity with each other's distinct technical expertise.

This paper posits that while many architecture and landscape architecture practices have grown closer in their vision of 21st-century urbanism and the distinct role that design can play in constructing high-performance, dynamic, vibrant cities, a shared creative project has not created a shared practice. Neither discipline has been able to replace or subsume the other, nor would this outcome necessarily be beneficial. The collective project of the city requires a diverse set of skills, methods, and perspectives including architects' facility with designing complex thermodynamic systems, developing innovative building materials and assemblies, understanding construction logistics and supply chains and balancing a diverse collection of user needs while designing structures of cultural significance. It also benefits from landscape architects' comfort with curating topographically complex sequences, organizing expansive territories, handling dynamic flows on site, and cultivating high-performance soils and vegetative communities.

In striving for new models of collaborative practice, designers might look to the multidisciplinary field of urban ecology for insight into how disparate disciplines may productively collaborate on a shared project of exploration and intervention without losing their disciplinary core, culture, methods, or perspective. Aside from serving as a model of collaboration, urban ecology also offers an inclusive framework of studying cities as socio-ecological systems that may help to overcome outdated and binary formulations of nature/culture, object/ field, and biotic/constructed. Rather than threatening the domain of architecture or landscape, urban ecology opens up conceptual space for a new and perhaps uncomfortable collaborative approach for the design of cities. Such a practice will require increased communication and new modes of collaboration in the service of a collective social, ecological, technological project. 


\section{THE LEGACY OF LANDSCAPE URBANISM}

At its inception, landscape urbanism grew out of conversations between landscape architects and architects who sought a disruption of traditional disciplinary territories, and in so doing aimed to transform the techniques and theory of contemporary urban design. ${ }^{2}$ These early voices in landscape urbanism shared a vision of the contemporary city as an expansive field condition organized around underlying ecological systems and infrastructural elements, dynamic in nature and continually evolving over time.

For nearly twenty years, proponents of landscape urbanism have argued for "a disciplinary realignment in which landscape supplants architecture's historical role as the basic building block of contemporary urbanism." ${ }^{3}$ Charles Waldheim sought to expand the traditional tools of landscape architecture so as to operate on expansive urban territories using light and nimble operational logics without having to rely on the "weighty apparatus of urban design - namely buildings." Still, within landscape urbanism's critique of architecture and mid-century planning, there has always been the germ of an interdisciplinary agenda: from the start, landscape urbanism attempted to operate between traditional disciplinary strongholds, exploiting its underdog status as a field without deep disciplinary history. As Stan Allen has described it, landscape urbanism sought to operate "not only in the void spaces between buildings, roadways, and infrastructure but in the spaces between disciplines as well." ${ }^{\prime 5}$

Landscape architects have used the theory of landscape urbanism to expand the scope and agency of their practice, beyond parks and gardens, to a scale that encompasses the organization of the contemporary city itself. ${ }^{6}$ This broad and inclusive definition of landscape encompasses both biological systems such as streams and woodlands, and infrastructural elements such as street networks, transit connections, water and sanitation services, and energy transmission conduits. ${ }^{7}$ Landscape architects bring to the conversation disciplinary experience with steering vegetation development over time, manipulating water flows, working with polluted sites and impacted urban soils, and managing flood risks - capacities increasingly in demand for large projects on degraded urban sites.

Architects operating on the urban landscape also see their agency as extending beyond the building envelope and indeed far past the single lot line. Increasingly, architects working on projects of all sizes see themselves as designing not just single buildings, but also the design of districts, infrastructure, logistics, and supply chains. Convening groups of diverse stakeholders and clients, some architecture practices are actively engaging with the ways in which buildings shape the urban environment through complex social, environmental and economic relationships and flows, regardless of whether or not landscape urbanism is explicitly acknowledged as an inspiration. Urbanistically, in the design of commercial, public, and institutional buildings, architectural interventions are often asked to imagine their impacts as extending far beyond the core program of a client or user group. Modernism's interest in exploring the boundary between inside and outside ${ }^{8}$ has only expanded as architects throw open the facade and embrace a wide range of relationships, from the social potential of dynamic and equitable streetscapes to the far-reaching impacts of a building's operations on a regional watershed or on global carbon budgets.

The early crop of landscape urbanism-inspired projects has now long been completed, or remain unbuilt, and by and large, the products of this theoretical challenge look disarmingly similar to those produced by conventional practice. At the very least, the conceptual project of landscape urbanism remains unfinished. Twenty years of landscape urbanism writing and discourse have not resulted in the creation of a new hybridized discipline, one better suited to meet the challenges of the contemporary city through complexity, informality, and play. It has not radically transformed the content of architectural education or the disciplinary center. It has not created a single, master discipline positioned to address this new urban vision.

Through its focus on programmed surfaces, charged fields, and staged dynamic happenings, landscape urbanism expanded the menu of strategies by which both architects and landscape architects might lightly and nimbly reorganize expansive territories. Landscape urbanism also sought to include an expanded field of collaborators in the process of urban design - from ecologists to developers, civil engineers, architects, landscape architects, and planners. But while acknowledging that the contemporary city was more unpredictable and dynamic than traditional planning approaches had previously admitted, landscape urbanism theory itself did not provide clear methods to unpack the nuanced social and ecological processes that it described as driving urban change. Landscape urbanism embraced vocabulary of ecological theory - concepts such as complexity, open-endedness, indeterminacy, and systems - but not the content of ecological science.

\section{URBAN ECOLOGY AS MODEL AND METHOD}

Ecology is at its core about relationships and systems, concerned since its origins in the 1800s with the study of the interaction of organisms with one another and with their environment. ${ }^{9}$ For most of its early existence, ecology concerned itself explicitly with the non-human world, and with the description of natural systems uncontaminated by human impacts. Generations of ecologists set out to study pristine landscapes untouched by human influence. Today, by contrast, few ecologists believe that such a pristine condition exists, nor is such isolation from human influence of service 
to a deep understanding of the contemporary ecological condition of the Anthropocene. ${ }^{10}$

At the forefront of this transformation in the sciences is the field of contemporary urban ecology, which defines people and their built works as part of the ecosystem, not outside of it. ${ }^{11}$ The conceptual core of contemporary urban ecology is an understanding of the city as a heterogeneous, complex, adaptive socio-ecological system - an integrated ecosystem consisting of biotic, physical, social, and built components. ${ }^{12}$ Contemporary urban ecology is an inherently multidisciplinary approach, a collaboration between environmental sciences, social sciences, engineering and design, that for the past thirty years has taken on the radical research agenda of moving from what is called an ecology in cities (the study of green spaces and remnant landscape patches) to an ecology of cities, which embraces the entirety of the city as an ecosystem, along with the varied mechanisms that drive urban pattern and processes as its object of study and intervention. ${ }^{13}$

Unlike classical ecologists, urban ecologists explicitly examine the interactions of the social, ecological, and technological domains that shape the structure and function of cities. They recognize that in urban areas, biological function is inevitably connected to social behavior and cultural perception - to a city's policies, institutions, funding decisions, and maintenance patterns, for example. These, in turn, are shaped by a community's opinions about, and interactions with, their local environment. Environmental scientists studying ecosystem patterns and processes in urban areas quickly realized that such study benefited immensely from the expertise and methodologies of social scientists, engineers, and designers in order to incorporate urban elements like property ownership, land-use history, demographics, or urban morphology alongside their direct observations of the biophysical world. This impulse has led to a proliferation of multidisciplinary studies and research projects where environmental scientists expand their capacity through collaboration, without losing grounding in their own disciplinary core competency.

The framework of urban ecology doesn't concern itself much with "nature." This is, after all, a "profoundly human construction" in the words of environmental historian William Cronon, that is more concerned with articulating what is natural and what is not, than with describing all how human and nonhuman systems interact with and affect each other. ${ }^{14}$ Instead, the social and technological components of the urban ecosystem are given as much weight by urban ecologists as the biophysical components. Any arrangement that assigns to landscape architects sole jurisdiction over the "natural" areas of a project both marginalizes the social and technological components of designed landscapes, while simultaneously excluding architects from engaging with dynamic ecosystem processes that support even constructed urban landscapes.
Both architects and landscape architects benefit from such a definition of urban ecosystem. The closer we look, the more we see that it is not so easy to separate the biotic from the constructed or technological in cities: consider for a moment the microbiome of a dwelling ${ }^{15}$ or the flows of energy and carbon bound up in building materials. ${ }^{16}$ While parks and gardens stand out more readily as living elements in an engineered gray matrix, populations of flora and fauna exist throughout the city ${ }^{17}$ and the entire urban matrix is interlaced with flows of water, nutrients, energy, and human labor. To better understand these interactions, it helps to look for systems, instead of focusing on the apparent architectural and landscape objects.

\section{THE PROBLEM WITH OBJECTS}

Both architecture and landscape struggle with object-ness. Architecture has long been caricatured as caring principally about formal conceits, de-emphasizing context and behavior in favor of the predictable imageability of the architectural figure. Some architectural theorists continue to argue for the primacy of form as a signifier of meaning and culture, whereas any building occupant knows that the richness of the life of a building extends far beyond its geometry and material selection.

Landscape architects can also easily fall into the trap of the objectification of systems and treating design elements as objects. Wetlands are often placed as readymades, and "habitat" treated as a programmatic filler or a stand-in for rich vegetative communities and layered ecological assemblages. ${ }^{18}$ Despite an understanding of soils, hydrology or vegetation as components of ecological systems, landscape objects such as paths, benches, play structures, trees, and shrubs are easier to draw.

In large, urban projects, landscape architects and architects are equally guilty of flattening their aspirations into an over-reliance on surfacing. For landscape architects, the landform lifts the surface into the air through dramatic topography - for example, Byxbee Park by George Hargraves, or more recently MVVA's Brooklyn Bridge Park and West 8's Governor's Island. Architects instead turn buildings on their side, creating a landscape surface of that is as much facade as roof - Yokohama Ferry Terminal by FOA or Olympic Sculpture Park by Weiss/Manfredi are two famous examples. Both disciplines hold out a special fondness for the uninterrupted, smooth technological surface. ${ }^{19}$

Topographic experiments have been co-opted by some architecture projects in an attempt to incorporate the larger set of landscape concerns, but all too often the landscape is rendered as mere surface, the ground reduced to a membrane - over-programmed, under-detailed and lacking in material richness. These technological surfaces - while they may be topographically interesting - are generally lacking in the 
biophysical complexity that Stan Allen had so admired in his description of the landscape ground as a thickened, dynamic mat:

"The 'thick 2D' of the landscape, is fundamental to the work that the meadow or the forest performs: the processing of sunlight, air, or water; the enrichment and protection of the soil through the process of growth and decay. In mat configurations, section is not the product of stacking (discrete layers, as in a conventional building section) but of weaving, warping, folding, oozing, interlacing, or knotting together." ${ }^{20}$

These dynamic qualities of living systems are difficult to harness if the focus remains on their formal organization, rather than on the underlying biological and ecological mechanisms that drive landscape change. If urban designers want to capture the essence of the contemporary city as not merely layered, but rather as composed of interconnected social, ecological, and technological systems - a "deep urbanism" - then they must engage more fully with environmental and social science. ${ }^{21}$

\section{SYSTEMS AND STRUCTURES THAT SUPPORT COLLABORATION}

Hybridity, from a disciplinary standpoint, implies a mixing or dilution of disciplinary expertise as an expression aimed at destabilizing power and hegemony. ${ }^{22}$ From a practice perspective, this could manifest in a complete merging (or "smoothing") of architecture and landscape into a mythical third condition, or perhaps the hybridization of landscape and architecture is happening at a finer scale in individual and collective practice and discourse.

Yet, the development of a shared project does not necessarily require a complete dissolution of identity and methods if one has confidence in the ability of multiple actors to productively collaborate towards a collective goal. Hybridity in landscape and architecture may instead look like a far less radical vision - the earnest sharing of methods from allied fields, to answer collective questions. For architects and landscape architects seeking models of collaboration, urban ecology's long road towards cross-disciplinary, collaborative research offers an example where neither environmental science nor social science seeks to overwhelm the other, but where practitioners of both disciplines work together in pursuit of complex research questions and indeed rely on the distance between their training to provide inspiration, innovation, and critical friction. ${ }^{23}$

From this perspective, urban ecology can also be understood as a theoretical framework - not a discipline unto itself, but a long-term cross-disciplinary conversation. It is a collective enterprise, whose continued development has required a diverse array of theoretical viewpoints, analytical methods, descriptive vocabularies and research cultures to both describe and communicate a synthetic vision of how urban ecosystems function as dynamic, complex systems. ${ }^{24}$ The central struggle for urban ecology theorists has not been whether their constituent disciplines ought to merge, but rather, whether or not their work represents a new or altered theory of urban systems. ${ }^{25}$

While the young field of urban ecology initially struggled to establish its credibility as a worthwhile subject of study, over the last three decades it has emerged as both a rapidly growing and critically relevant discipline increasingly well positioned to address critical ecological performance challenges of the next century. As urban ecologists seek to move beyond describing urban systems and towards more active interventions in the built environment, particularly concerning the topic of urban resilience, ecosystem services and adaptation to climate change, there has been greater recognition of the need for urban ecologists to collaborate more closely with engineers, architects, and designers. ${ }^{26}$

Multidisciplinary collaboration is simple in theory, and difficult in practice. It takes time, interest and patience to become familiar enough with the content and culture of another discipline to establish a shared vocabulary, overcome misunderstandings, and build relationships. Deep collaboration is borne out of practice and trust. Such engagement and relationships necessarily require more time than a single design project allows. Here, the expansion of urban ecological research offers a final lesson. Urban ecology has gained momentum in the last two decades in large part through the ongoing work of a number of funded, long-term research programs such as the National Science Foundationsupported Long Term Ecological Research (LTER) sites. The LTER program began in the 1980s, establishing 26 research sites across all ecoregions of the United States. A decade later, the LTER program was expanded to include two urban sites: Baltimore and Phoenix. The Baltimore Ecosystem Study and the Phoenix LTER have resulted in the publication of over a thousand articles, books, and chapters co-authored by a diverse army of environmental and social scientists over their 20-year history. ${ }^{27}$

What would constitute a similar long-term structure for ongoing collaboration between architecture and landscape, underpinned by funded collaboration over multiple years? What forms of institutional support and training would enable architects and landscape architects to collaborate better? Are our educational programs sufficiently focused on teaching skills of collaboration and research to prepare young designers to work on complex, synthetic projects and to understand and respect the valuable skills, methods, and perspectives that our collaborators bring to the table? Are current modes of practice nimble enough to support longterm engagement and relationships beyond the structure of 
the individual project? What roles will be available to designers looking to engage in interdisciplinary practice?

Finally, what is the role for designers with multiple backgrounds, who move between disciplinary camps? The irony, of course, is that some of landscape architecture's leading theorists and practitioners were once architects. While perhaps few in number, there are indeed landscape architecture and architecture students currently in graduate design programs or in practice who had other, serious interests and training before they arrived. Will the profession make use of their unique abilities to engage and translate between architecture and other disciplines?

There is value in retaining disciplinary modes and methods when tackling complex design problems, but these traditional core skills are not enough today. Landscape urbanism articulated the provocation of a new hybrid design discipline, opening up the conceptual territory for collaboration and introducing landscape and architecture to new strategies outside their comfort zones. Today's urban challenges demand similarly nimble strategies, but with a firmer grounding in the socio-ecological feedbacks and mechanisms that drive the function and performance of urban sites. This means the active incorporation of metrics, monitoring, and adaptive management into an ongoing long-term design engagement. By focusing on the infrastructural, avoiding the overly visual, and getting past the caricature of "nature," architects, landscape architects, and urban ecologists might begin crafting a shared vocabulary, a necessary first step towards a shared practice.

\section{ENDNOTES}

1 Timon McPhearson, Dagmar Haase, Nadja Kabisch, and Åsa Gren, "Advancing Understanding of the Complex Nature of Urban Systems," Ecological Indicators 70 (2016): 566-73.

2 James Corner, "Terra Fluxus" in The Landscape Urbanism Reader, ed. Charles Waldhiem (New York: Princeton Architectural Press), 23.

3 Charles Waldheim, "Landscape as Urbanism," in The Landscape Urbanism Reader, ed. Charles Waldheim (New York: Princeton Architectural Press, 2006), 37.

4 Charles Waldheim, "Precedent for the North American Landscape Urbanism," in Center 14: On Landscape Urbanism, ed. Dean Almy (Austin: Center for American Architecture and Design, School of Architecture, the University of Texas at Austin, 2007), 292.

5 Stan Allen, "Landscape Infrastructures" in Infrastructure as Architecture: Designing Composite Networks, eds. Katrina Stoll and Scott Lloyd (Berlin: Jovis, 2010), 38.

6 Charles Waldheim, "Introduction: A Reference Manifesto" in The Landscape Urbanism Reader, ed. Charles Waldhiem (New York: Princeton Architectural Press), 15.

7 Anne W. Spirn, The Granite Garden: Urban Nature and Human Design (New York: Basic Books, 1985).

8 David Leatherbarrow, Uncommon Ground: Architecture, Technology, and Topography (Cambridge \& London: MIT Press, 2000), 27.

9 F. Stuart Chapin III, Pamela A. Matson, and Harold A. Mooney, Principles of Terrestrial Ecosystem Ecology (New York: Springer, 2002), 3.

10 Erle C. Ellis, Kees Klein Goldewijk, Stefan Siebert, Deborah Lightman, and Navin Ramankutty, "Anthropogenic Transformation of the Biomes, 1700 to 2000," Global Ecology and Biogeography 19, no. 5 (2010): 589-606; Erle C. Ellis, "Ecology in an Anthropogenic Biosphere," Ecological Monographs 85, no. 3 (2015): 287-331.
11 Morgan J. Grove, Mary Cadenasso, S.T.A. Pickett, Gary E. Machlis, and William R. Burch, The Baltimore School of Urban Ecology: Space, Scale and Time for the Study of Cities, 1st ed. (New Haven: Yale University Press, 2016), 172-91.

12 Nancy B. Grimm, Stanley H Faeth, Nancy E Golubiewski, Charles L Redman, Jianguo Wu, Xuemei Bai, and John M Briggs, "Global Change and the Ecology of Cities," Science 319, no. 5864 (February 8, 2008): 756-760.

13 Mary Cadenasso and Steward Pickett, "Urban Principles for Ecological Landscape Design and Management: Scientific Fundamentals," Cities and the Environment 1, no. 2 (2008): 1-16, http://digitalcommons.Imu.edu/cate/vol1/ iss $2 / 4 /$.

14 William Cronon, "Introduction: In Search of Nature," in Uncommon Ground: Rethinking the Human Place in Nature, ed. William Cronon (New York \& London: W.W. Norton \& Co., 1996), 25.

15 Steven W. Kembel, James F. Meadow, Timothy K. O'Connor, Gwynne Mhuireach, Dale Northcutt, Jeff Kline, Maxwell Moriyama, G. Z. Brown, Brendan JM Bohannan, and Jessica L. Green, "Architectural design drives the biogeography of indoor bacterial communities," PloS one 9, no. 1 (2014): e87093.

16 Stephanie Carlisle, "Getting Beyond Energy: Environmental Impacts, Building Materials, and Climate Change," in Embodied Energy and Design: Making Architecture Between Metrics and Narratives, ed. David Benjamin (New York City: Columbia University GSAPP and Lars Muller Publishers, 2017), 165-77.

17 P.W. Bateman and P. A. Fleming, "Big City Life: Carnivores in Urban Environments," Journal of Zoology 287 (2012): 1-23.

18 Nigel Dunnett and James Hitchmough, eds., The Dynamic Landscape: design, ecology and management of naturalistic urban planting (New York: Taylor \& Francis, 2007);

19 Travis Beck, "Maintaining the World as We Know It: Biodiversity for High Functioning Landscapes" in Principles of Ecological Landscape Design (Washington, Covelo, London: Island Press, 2013);

20 Thomas Rainer and Claudia West, Planting in a Post-Wild World: Designing Plant Communities for Resilient Landscapes (Portland: Timber Press, 2015)

21 Alex Wall, "Programming the Urban Surface," in Recovering Landscape: Essays in Contemporary Landscape Architecture, ed. James Corner (New York: Princeton Architectural Press, 1999), 233-249.

22 Stan Allen, "Mat Urbanism: The Thick 2-D," in CASE \#2: Le Corbusier's Venice Hospital and the Revival of the Mat Building, ed. Hashim Sarkis (Munich: Prestel, 2001), 125.

23 Stephanie Carlisle and Nicholas Pevzner, "The Performative Ground: Rediscovering the Deep Section," Scenario Journal 02: Performance (Spring 2012), https://scenariojournal.com/article/the-performative-ground/.

24 Homi K. Bhabha, The Location of Culture (New York: Routledge, 1994).

25 Timon McPhearson, Dagmar Haase, Nadja Kabisch, and Åsa Gren, "Advancing Understanding of the Complex Nature of Urban Systems." Ecological Indicator 70 (2016): 566-73

26 Steward T.A. Pickett, Mary L. Cadenasso, and Brian McGrath, "Ecology of the City as a Bridge to Urban Design," in Resilience in Ecology and Urban Design (New York: Springer, 2013), 7-28.

27 Steward T.A. Pickett, Mary L. Cadenasso, J. M. Grove, Christopher G. Boone, Peter M. Groffman, Elena Irwin, Sujay S. Kaushal, et al., "Urban Ecological Systems: Scientific Foundations and a Decade of Progress," Journal of Environmental Management 92, no. 3 (2011): 331-62.

28 Timon McPhearson, "Scientists must have a say in the future of cities," NATURE, vol. 538, p. 165-166, 2016;

29 Nancy Grimm, E.M. Cook, R.L. Hale, D.M. Iwaniec. "A broader framing of ecosystem services in cities: Benefits and challenges of built, natural, or hybrid system function," in eds., K.C. Seto, W. Solecki, and C.A. Griffith, The Routledge Handbook of Urbanization and Global Environmental Change (New York: Routledge, 2016);

30 Jack Ahern, Sarel Cilliers, Jari Niemelä, "The concept of ecosystem services in adaptive urban planning and design: A framework for supporting innovation," Landscape and Urban Planning 125 (2014): 254-259;

31 Steward T.A. Pickett, Christopher G. Boone, Brian P. McGrath, M. L. Cadenasso, Daniel L. Childers, Laura a. Ogden, Melissa McHale, and J. Morgan Grove, "Ecological Science and Transformation to the Sustainable City," Cities 32 (2013).

32 Morgan J. Grove, Mary Cadenasso, Steward T.A. Pickett, Gary E. Machlis, and William R. Burch, The Baltimore School of Urban Ecology: Space, Scale and Time for the Study of Cities, 1st ed. (New Haven: Yale University Press, 2016): 172-91. 